\title{
The Hicks' Concept of Income and Its Relevancy for Accounting Purposes
}

\author{
David PROCHÁZKA*
}

\section{Introduction}

Income and profit are the basic economic categories, which are a subject of detailed scientific research in economics and in accounting theory as well. Experts' discussions are often very passionate as far as the nature and determination of income concern. In my opinion, the accounting concept of income should reflect the economic principles. Proper analysis requires deep study of all relevant sources of economic literature on this topic. In this paper, I will concentrate on the "father of modern economic income theory". John Richard Hicks published his famous "Value and Capital" in 1939. The part devoted to income was short in extent but it had a big impact on the development of the future research.

\section{Background and motivation for the paper}

Income determination is a central part of accounting theory. Practical problems with the determination of income are most discussed by standard setters, preparers and users of financial statements as well. In recent years, worldwide accounting standards - American Generally Accepted Accounting Principles (US GAAP) and International Financial Reporting Standards has been experiencing a big conceptual shift. The crucial factor underlying this change is the adherence to fair value measurement, which importance within the FASB and IASB pronouncements is steadily growing. Modern financial reporting has been

\# The paper is processed as an output of a research project Analysis of Accounting Standards for Income Reporting - New Approaches in the World and the Possibilities of Their Utilisation in the Czech Republic (registration number GA402/09/P523).

Ing. David Procházka, Ph.D. - assistant professor; Department of Financial Accounting and Auditing, Faculty of Finance and Accounting, University of Economics, Prague, W. Churchill Sq. 4, 13067 Prague 3, Czech Republic; <prochazd@vse.cz>. 
shifting towards fair value accounting, which has been replacing traditional historical cost model.

Because of recent development in standard-setting process, the fair value measurement has become pervasive to financial reporting and has resulted in unprecedented shift in the content, significance and usefulness of information about financial situation and performance. The accounting perception of economic phenomena and the way how to present the economic course of an entity's life in financial statements is altering so enormously that some authors, e.g. Barlev (2003) or Hitz (2007), talk about change in accounting paradigm. However, the new paradigm elicits cardinal questions regarding financial reporting. Characteristics, nature and usefulness of information on income are the most discussed topics once again.

The evaluation of financial performance critically depends on the capital maintenance concept employed. Capital maintenance approach to determination of entity's income implies that income is recognized after capital has been maintained or costs have been recovered. Belkaoui (2004, p. 483) recognizes four ways of capital maintenance based on SFAC 5.45-48 (FASB, 1984):

- money maintenance when financial capital measured in money units is to be maintained;

- general purchasing-power money maintenance when financial capital measured in units of the same purchasing power is to be maintained;

- productive-capacity maintenance when physical capital measured in money units is to be maintained;

- general purchasing-power productive-capacity maintenance when physical capital measured in units of the same purchasing power is to be maintained.

Practical solutions of problems relating income determination could be inspired by the theoretical contributions to this issue. We can distinguish two directions in the income (or profit) theory. Concepts of capital, income and value create the integral part of both economic and accounting theories of income. Fisher (1906, 1930), Knight (1921), Hicks (1946) or Mises (1966) introduced the most important economic concepts of income. In accounting theory, the most famous concepts of income were developed by MacNeal (1939), Edwards and Bell (1961) or 
Chambers (1974). All authors prefer income concept based on capital maintenance. E.g. MacNeal (1979, p. 87) preferred the measurement of all accounting elements by the economic value, Edwards and Bell (1973, p. 45 and fol.) introduced opportunity costs for determination of expected realizable profit and current costs for determination of business profit or Chambers (1974, p. 92) worked with current cash equivalents.

The paper aims to analyze the most important economic theory of income worked out by J. R. Hicks. Firstly, I will briefly describe the Hicks' concept of income. In the next analytical section, I will expose some weaknesses of his theory that impede its utilization in financial reporting. Despite these shortcomings, the economic concept of income cannot be freezed out for accounting purposes.

\section{Basic characteristics of the Hicks' concept of income}

\section{The nature of income}

Hicks describes the nature and function of income under two organizations of economy - static and dynamic. There is no difficulty with the definition of income in the static, i.e. non-growing economy. The amount of a weekly receipt is the income of the individual if s/he does not expect any change in economic conditions and if s/he anticipates a constant flow of monetary receipts in each further week. Nevertheless, what would be income for a week if the salary were paid out on a monthly basis? Could we assert that the income is equal to zero? Probably not! The question stands how to determine the amount of income under such a situation?

"The purpose of income calculations in practical affairs is to give people an indication of the amount they can consume without impoverishing themselves" (Hicks, 1946, p. 172). Based on this proposition Hicks defines "a man's income as the maximum value which he can consume during a week, and still expect to be as well of at the end of period as he was at the beginning" (Hicks, 1946, p. 172). ${ }^{1}$ If a man saves, he is planning to be better of in the future than he is now. If a man spends more than his income is, he is planning to deteriorate his wellbeing. Hicks states that his definition of income fully corresponds to the

1 Hicks regards this definition as central (major). All practical computation should be in line with the central definition. 
requirement so that the income is a guide for prudent management. „Remembering that the practical purpose of income is to serve as a guide for prudent conduct, I think it is fairly clear that this is what the central meaning (of income - author's note) must be." This assertion should be subject of interest from the accounting perspective.

\section{Practical approximation of the theoretical concept of income}

In practice, we have to employ approaches that are only approximations of the central definition of income because we do not have any exact measure of the well-being at disposal. Let us assume a man's wealth comprises certain property (e.g. securities, plants, etc.) generating cash inflows. The rate of return on capital is at $0.1 \%$ a week and the value of his wealth at the beginning of the week is $10010 \mathrm{CU}$. If the individual spends the amount of $10 \mathrm{CU}$ and invests the rest at the market rate of return, the accumulated value of his wealth will finally be $10010 \mathrm{CU}$. This equals to the initial value of his wealth. Hicks notates this approximation by the term Income 1. It is "the maximum amount, which can be spent during a period if there is to be an expectation of maintaining intact the capital value of prospective receipts (in money terms)" (Hicks, 1946, p. 173).

Income 1 is easily utilizable under unchanging economic conditions influencing the amount of income. Nevertheless, if the interest rate fluctuates the first approximation is not sustainable. Suppose that the man expects the interest rate to rise to $0.2 \%$ during the second week. Equation (1) expresses the cash flows according to Income $\mathbf{1}$ as that they are expected at the beginning of the first week. The expectation of future cash flows as at the beginning of the second week is expressed in Equation (2).

$$
\begin{aligned}
& I_{1}=\{10,20,20,20, \ldots\} \\
& I_{2}=\{20,20,20,20, \ldots\}
\end{aligned}
$$

Therefore, Hicks introduces the second approximation of the general concept of income. He defines Income $\mathbf{2}$ as "the maximum amount the individual can spend during a week, and still expect to be able to spend the same amount in each ensuing week" (Hicks, 1946, p. 174). Income 2 is getting nearer to the central definition of income, especially when interest rates are changing. Despite this advantage, even this approximation fails when taking into account changing market prices. 
Income 3 includes these changes and it is defined as "the maximum amount of money which individual can spend this week, and still expect to be able to spend the same amount in real terms in each ensuing week" (Hicks, 1946, p. 174). In my opinion, Income 3 can be alternatively defined as the maximum amount that individual can consume during a week and still expect that he will able to consume this amount in real terms in each next week." The monetary spending in real terms corresponds to the physical consumption of goods and services by the individual. However, the unambiguous measurement of consumption is unattainable.

\section{The distinction of income ex-ante and income ex-post}

Hicks consolidates his exposition by practical examples of income computation. He remarks the distinction between two time dimensions of income, which are labeled by the terms of income ex-ante and income expost. At the beginning of the week, an individual holds a stock of goods and expects a flow of receipts for which he will be able to buy new goods in the future. Hicks calls this status as Prospect I. At the end of the week, the individual knows that the first week of the prospect has just finished. A new Prospect II is arising and the individual updates the plan of expected cash flows.

The first week of the Prospect II is the second week of the former Prospect I. Neither the Prospect II is not (exactly) known at the time of setting up the Prospect I, nor is the Prospect I available at the time of the Prospect II. If it would be so, the individual could easily decide which alternative of future development is preferable. Consequently, this would lead to the irrelevancy of the income and its utilization in economic behavior. However, above-mentioned possibilities are not attainable and the principal question sounds how much can an individual consume during a week without impoverishing himself.

According to Hicks, the income is the main guide for making decisions about future consumption. This is the reason why he tries to outline the method of income determination for a period at the start of that period. This is the nature of ex-ante income, which is equal to the difference between Prospect II and Prospect I from the time perspective of Prospect I. For a qualified decision, it is necessary to estimate the status at the beginning of Prospect II. Income ex-ante is therefore a wholly estimated category. 
The income ex-ante corresponds to the Hicks' view of income nature. We have to estimate how much will the wealth of an individual be at the end of the period which is about to come in order to calculate the possible level of his consumption and his income during this period. It is necessary to establish a criterion for the comparison of the wealth at the beginning and at the end of the period. The criterion, i.e. the time sequence of decisions taken, helps to evaluate the consumption during the period. By comparing initial and final position at the beginning of the period (i.e. at the starting point of Prospect I), we can derive income ex-ante. The second computation of income can be made from the perspective of Prospect II, i.e. at the end of the period. This income is called ex-post.

\section{The analysis of the Hicks' income}

The crucial point for a successful utilization of the Hicks' theory in practice is the definition and the measurement of the well-being of the economic entity. According to Hicks, the income can be measured as the difference of a man's wealth at the end and at the beginning of the period. The measurement of the income requires the measurement of the individual's wealth (capital). With reference to the principles of economic behaviour, Hicks states that the value of capital is the present value of expected cash inflows. Cash flows are discounted to the start and to the end of the period for which the income is measured. The difference is the income, i.e. the amount that an individual can consume during the period without impoverishing himself.

\section{The income ex-ante - the formula for the first period}

A substantial part of Hicks' work is devoted to income ex-ante. Income ex-ante is computed to the beginning of Prospect I (it could be a week, a month, or a year) and it measures the amount of expenditures for consumption goods so that the individual could still expect that the value of his capital at the end of Prospect I will not decrease below its initial value. The value of income ex-ante is the capitalized value of the expected cash inflows from economic activities of the individual. At the beginning of Prospect $I$, value of the capital $K_{0, \exp }$ to the starting point of this prospect has to be computed. Value of the capital is equal to the present value of the future (net) cash inflows. As the second step, an estimation of value of the capital $K_{1, \exp }$ to the end of the Prospect I should be made. This estimate is carried out at the beginning of the period and it 
uses the same data as the computation of $K_{0, \text { exp }}$. The formal expression is shown in the Equations 3 - 5. (Assumption: cash flows are incurred at the end of the period.)

$$
K_{0, \exp }=\sum_{j=1}^{n} \frac{N C F_{j}}{(1+i)^{j}},
$$

where $K_{0, \exp }=$ the value of the capital at the beginning of year 1 from the view of Prospect I,

$N C F_{j}=$ the net cash inflow in year $j$,

$n \quad=$ the time span for which are the cash flows projected,

$i \quad=$ the discount rate.

$$
K_{1, \exp }=\sum_{j=2}^{n} \frac{N C F_{j}}{(1+i)^{j-1}}+N C F_{1},
$$

where $K_{1, \exp }=$ the value of the capital at the end of year 1 from the view of Prospect I,

$N C F_{j}=$ the net cash inflow in year $j$,

$n \quad=$ the time span for which are the cash flows projected,

$i \quad=$ the discount rate.

$I_{1}$ ex-ante $=K_{1, \exp }-K_{0, \exp }=i \cdot K_{0, \exp }$,

where $\quad I_{1, e x-a n t e}=$ the income ex-ante expected for Prospect $I$,

$K_{1, \exp }=$ the expected value of the capital at the end of Prospect I,

$K_{0, \exp }=$ the value of the capital at the beginning of Prospect II,

$i \quad=\quad$ the discount rate

The difference between capitalized values of expected inflows as at the beginning and the end of Prospect $I$ is income ex-ante. It is the amount that an individual can consume during a week, and still expect to be as wealthy at the end of period as he was at the beginning. This proposition holds as long as the real course of actions corresponds to the expectations. The volume of the income can be alternatively derived as the interest (at the discount rate) from the initial value of the capital $K_{0, \text { exp }}$. 
Procházka, D.: The Hicks' Concept of Income and Its Relevancy for Accounting Purposes.

\section{The income ex-ante - an illustrative example}

Mr. Adam Smith is the owner of several production factors and he hires them to other market participants. He expects to receive regular cash receipts amounting 10000 annually during the next 4 years.

\section{Additional assumptions:}

- each prospect lasts one year, i.e. Prospect I corresponds to year 2000 ,

- cash inflows are received at the end of the year,

- the discount rate is $10 \%$.

Table 1 summarizes all necessary calculation needed to ascertain value of the capital at the beginning of Prospect $I$. The length of the prospect is one year; at each year-end Mr. Smith obtains a cash flow amounting 10000 . These cash flows are discounted at $10 \%$ and value of the capital $K_{0, \exp }$ as at the start of Prospect $I$ is 31 698.7. We should apply similar procedure when computing value of the capital as at the end of Prospect I. At the end of Prospect I Mr. Smith receives an inflow of 10000 which is not to be discounted (or better said the discount factor is equal to one). The expected cash flows for next years are discounted, the factor is shifted by one year in comparison with the computation of $K_{0, \exp }$. Present value of the capital $K_{1, \exp }$ as at the end of Prospect I (but estimated already at the beginning of this prospect) is 34868.5 . The end of Prospect I is simultaneously the beginning of Prospect II.

Tab. 1: The value of the capital $K_{0, \text { exp }}$ as at the beginning of Prospect I

\begin{tabular}{|c|c|c|c|}
\hline Year & Expected CF & Discount factor & PV of expected CF \\
\hline $\mathbf{2 0 0 0}$ & 10000 & 0.90909 & 9090.9 \\
\hline $\mathbf{2 0 0 1}$ & 10000 & 0.82645 & 8264.5 \\
\hline $\mathbf{2 0 0 2}$ & 10000 & 0.75132 & 7513.2 \\
\hline $\mathbf{2 0 0 3}$ & 10000 & 0.68301 & 6830.1 \\
\hline Prospect I & & & $\mathbf{3 1 6 9 8 . 7}$ \\
\hline
\end{tabular}


Tab. 2: The value of the capital $K_{1, \exp }$ as at the beginning of Prospect I

\begin{tabular}{|c|c|c|c|}
\hline Year & Expected CF & Discount factor & PV of expected CF \\
\hline $\mathbf{2 0 0 0}$ & 10000 & 1.00000 & 10000.0 \\
\hline $\mathbf{2 0 0 1}$ & 10000 & 0.90909 & 9090.9 \\
\hline $\mathbf{2 0 0 2}$ & 10000 & 0.82645 & 8264.5 \\
\hline $\mathbf{2 0 0 3}$ & 10000 & 0.75131 & 7513.1 \\
\hline Prospect II & & & $\mathbf{3 4 8 6 8 . 5}$ \\
\hline
\end{tabular}

The volume of the income ex-ante expected by an individual for Prospect $I$ is 3 169.8. From the economic point of view, the income exante is the difference between $K_{1, \exp }$ and $K_{0, \exp }$. This amount is equal to $10 \%$ of initial value of the capital $K_{0, \exp }$. If the real course of actions is in concord with his expectations, Mr. Smith's maximal consumption could reach the amount of 3169.8 . If his expectations are not fulfilled, the real volume of the capital $K_{1, \exp }$ could be higher (smaller) than estimated at the beginning of the period.

It has to be stressed once again that Prospect II (i.e. the value of the capital as at the end of the period) is already computed at the beginning of Prospect I. Therefore, Prospect I and Prospect II constitute the same expectations. They differ only by the moment to which the expected cash flows are discounted. Therefore, the income ex-ante is in its nature estimation. It is an estimated amount, which could be consumed during the period without lowering the initial value of the capital.

\section{The income ex-ante - the model generalization}

The computation of the income ex-ante for the next period uses the same logic as in the case of Prospect I. Let us suppose that the former expectations do not change for the year 2001 (Prospect II). After deducting the value of the capital at the beginning of this period from its value at the end of year 2001, we can conclude that income ex-ante for Prospect II amounts 2486.9. 
Procházka, D.: The Hicks' Concept of Income and Its Relevancy for Accounting Purposes.

Tab. 3: The value of the capital $K_{1, \exp }$ as at the beginning of Prospect II

\begin{tabular}{|c|c|c|c|}
\hline Year & Expected CF & Discount factor & PV of expected CF \\
\hline $\mathbf{2 0 0 1}$ & 10000 & 0.90909 & 9090.9 \\
\hline $\mathbf{2 0 0 2}$ & 10000 & 0.82645 & 8264.5 \\
\hline $\mathbf{2 0 0 3}$ & 10000 & 0.75131 & 7513.1 \\
\hline Prospect II & & & $\mathbf{2 4 8 6 8 . 5}$ \\
\hline
\end{tabular}

Tab. 4: The value of the capital $K_{2, \exp }$ as at the beginning of Prospect II

\begin{tabular}{|c|c|c|c|}
\hline Year & Expected CF & Discount factor & PV of expected CF \\
\hline $\mathbf{2 0 0 1}$ & 10000 & 1.00000 & 10000.0 \\
\hline $\mathbf{2 0 0 2}$ & 10000 & 0.90909 & 9090.9 \\
\hline $\mathbf{2 0 0 3}$ & 10000 & 0.82645 & 8264.5 \\
\hline Prospect III & & & $\mathbf{2 7 3 5 5 . 4}$ \\
\hline
\end{tabular}

Generalizing the previous calculations (assuming that cash inflows incur at the end of the prospect), we can reach the conclusion that income ex-ante for any Prospect $m$ (where $m$ is a positive integer number) can be derived as it is shown in Equation 6.

$$
I_{m},_{e x-a n t e}=K_{m, \exp }-K_{m-1, \exp }=i \cdot K_{m-1, \exp },
$$

where $I_{m, e x-a n t e}=$ the income ex-ante expected for Prospect $m$,

$K_{m, \exp }=$ the value of the capital (expected) at the end of Prospect m,

$K_{m-1, \exp }=$ the value of the capital at the beginning of Prospect $m$,

$i=$ the discount rate

$$
K_{m-1, \exp }=\sum_{j=m}^{n} \frac{N C F_{j}}{(1+i)^{j}},
$$

where $K_{m-1, \exp }=$ the value of the capital at the beginning of Prospect $m$,

$N C F_{j}=$ the net cash inflow for year $j$,

$n \quad=$ the time span for which cash flows are projected,

$i=$ the discount rate. 


$$
K_{m, \exp }=\sum_{j=m+1}^{n} \frac{N C F_{j}}{(1+i)^{j-1}}+N C F_{m},
$$

where $K_{m, \exp }=$ the value of the capital (expected) at the end of Prospect m,

$N C F_{j}=$ the net cash inflow for year $j$,

$n \quad=$ the time span for which cash flows are projected,

$i \quad=$ the discount rate.

Income ex-ante for a certain period is the difference between values of the capital at the end and the beginning of that period. Value of the capital is the present value of the expected cash inflows discounted to the end and to the beginning of the period. It could be shown that income ex-ante for Prospect $m$ is equal to the interest from the value of the capital as at the beginning of Prospect $m$. The income ex-ante is an estimated variable depending on:

- the amount and distribution of cash inflows in a particular prospect of time span for which inflows are projected,

- the length of the time span,

- the length of one prospect,

- the level of the discount rate.

\section{The income ex-post - unchanging parameters influencing the income}

So far, I have been analyzing income ex-ante. Income ex-ante is the amount, which could be according to the opinion of an individual consumed during the period. The calculation of this income is made at the start of the period. However, we cannot omit the subsequent evaluation of expectations. In other words, we also have to keep an eye on income expost. Likewise income ex-ante, income ex-post is the difference between two values of capital. The crucial difference between both concepts of income is the moment of time at which income is calculated. Income exante is computed at the beginning of the period, the calculation of income ex-post is made at the end of the same period.

At the end of Prospect I an individual knows the exact amount of cash inflow for the first period of time span for which he ascertains his income. 
Therefore, he has all necessary data to calculate actual capital value as at the end of Prospect I. This value is of course equal to the present value of future cash inflows. When computing income ex-post, two possible situations can occur:

1. the real income ex-post equals the expected income ex-ante,

2. the real income ex-post diverges from the expected income ex-ante.

The first alternative occurs if all conditions are met simultaneously:

a) the real cash receipts for Prospect $I$ are equal to the receipts expected at the beginning of Prospect I,

b) the expected volume and time distribution of future cash inflows are the same as at the beginning of Prospect I,

c) the expectations of the discount rate level remain unchanged.

Taking into account the data from the illustrative example we can state that Mr. Smith's income ex-post reaches the same amount as income ex-ante only if:

- Mr. Smith receives exactly the amount $10000 \mathrm{CU}$ at the end of Prospect I,

- he still expects to receive the same amount $10000 \mathrm{CU}$ in each of the next three years,

- the expected discount rate remains at the $10 \%$ level.

If these three conditions are met, value of the capital at the end of Prospect I (computed after the end of this prospect) is 34868.5 . This corresponds to the expectations from the beginning of the period constituted by income ex-ante. There is no variation between actual and expected cash inflows for the period. Anticipations of the future cash inflows and the discount rate are the same. Initial value of the capital revised at the end of the period remains the same (i.e. 31 689.7) and therefore income ex-post matches with income ex-ante.

\section{The income ex-post - the deviation of the actual cash inflow from expected one}

If all above-mentioned conditions are met, income ex-post matches with income ex-ante automatically. However, this is not a realistic 
assumption. A much more interesting situation arises when the conditions do not hold. Income ex-post departs from income ex-ante if:

1. the real and the expected volume of cash inflows for Prospect I are different,

2. at the end of Prospect $I$ an individual changes his estimation regarding:

a) the cash inflows for the following prospects,

b) the level of the rate at which are the cash inflows discounted. ${ }^{2}$

Let us suppose that Mr. Smith receives $9000 \mathrm{CU}$ instead of the expected amount of $10000 \mathrm{CU}$ at the end of the year 2000. Moreover, Mr. Smith assumes this change as a temporary shock, which will not influence his expectation regarding the future cash inflows. Tables $5-6$ summarize the computation of income ex-post.

Tab. 5: The value of the capital $K_{0, \exp }$ as at the end of Prospect I different cash flow

\begin{tabular}{|c|c|c|c|}
\hline Year & Expected CF & Discount factor & PV of expected CF \\
\hline $\mathbf{2 0 0 0}$ & 9000 & 0.90909 & 8181.8 \\
$\mathbf{2 0 0 1}$ & 10000 & 0.82645 & 8264.5 \\
$\mathbf{2 0 0 2}$ & 10000 & 0.75131 & 7513.1 \\
$\mathbf{2 0 0 3}$ & 10000 & 0.68301 & 6830.1 \\
\hline Prospect I & & & $\mathbf{3 0 7 8 9 . 6}$ \\
\hline
\end{tabular}

Tab. 6: The value of the capital $K_{1, \exp }$ as at the end of Prospect I different cash flow

\begin{tabular}{|c|c|c|c|}
\hline Year & Expected CF & Discount factor & PV of expected CF \\
\hline $\mathbf{2 0 0 0}$ & 9000 & 1.00000 & 9000.0 \\
$\mathbf{2 0 0 1}$ & 10000 & 0.90909 & 9090.9 \\
$\mathbf{2 0 0 2}$ & 10000 & 0.82645 & 8264.5 \\
$\mathbf{2 0 0 3}$ & 10000 & 0.75131 & 7513.1 \\
\hline Prospect II & & & $\mathbf{3 3 8 6 8 . 5}$ \\
\hline
\end{tabular}

2 There is a possibility of combination of all factors, too. 
After updating the plan of cash flows by actual receipt for Prospect I, income ex-post amounts 3 078.9. Income ex-post is smaller by $90.9 \mathrm{CU}$ than income ex-ante because the actual cash inflow for Prospect I was smaller than forecasted by $1000 \mathrm{CU}$. The smaller cash inflow leads to the decrease in value of the capital at the beginning and at the end of period as well. While final value of the capital sinks down by the nominal value of the cash inflow change, the initial value of the capital goes down by the discounted value of that decline (i.e. decline by 909.1 at the discount rate $10 \%$ ). The difference of 90.9 between those values is equal to the variation of income ex-post from income ex-ante due to lower actual receipt. If expectations do not alter and if actual cash flows are the same as forecasted cash flows, income ex-post will match with income ex-post again.

\section{The income ex-post - changes in the expectations regarding the cash flows}

The solution of a different actual cash inflow from the expected one is not conceptually complicated. The discrepancy between the anticipation and the reality leads only to the departure of the income ex-ante from the income ex-post for the prospect at which the difference occurs. A far more interesting complication arises if there is a change in anticipated future cash flows. Let us assume that at the end of the year $2000 \mathrm{Mr}$. Smith expects a permanent decrease in future cash inflows by $1000 \mathrm{CU}$ annually (i.e. he expects that he will receive $9000 \mathrm{CU}$ annually in next three years).

Tab. 7: The value of the capital $K_{1, \exp }$ at the end of Prospect I change in expectations

\begin{tabular}{|c|c|c|c|}
\hline Year & Expected CF & Discount factor & PV of expected CF \\
\hline $\mathbf{2 0 0 0}$ & 10000 & 1.00000 & 10000.0 \\
$\mathbf{2 0 0 1}$ & 9000 & 0.90909 & 8181.8 \\
$\mathbf{2 0 0 2}$ & 9000 & 0.82645 & 7438.0 \\
$\mathbf{2 0 0 3}$ & 9000 & 0.75131 & 6761.8 \\
\hline Prospect II & & & $\mathbf{3 2 ~ 3 8 1 . 6}$ \\
\hline
\end{tabular}

The calculation of income based on the reviewed expectations implies that the change of anticipations influences value of the capital at the end 
of Prospect I and the volume of the income ex-post as well. Income expost for Prospect I is $683 \mathrm{CU}(32281.6$ - 31 698.6) and it is by 2486.8 $\mathrm{CU}$ smaller than income ex-ante due to the change in expectations. We can conclude that both unfulfilled expectations (i.e. a different actual cash flow for the period from the forecasted flow) and change in expectations (i.e. a shift in anticipation of future cash inflows) cause the discrepancy between income ex-ante and ex-post for that particular period.

We can argue that the change in expectations is of a qualitatively different nature than unfulfilled expectations. As the time goes by, market participants get better information and can refine their estimations regarding future development. If the previous assumptions are unattainable, economic subjects naturally change their expectations and adjust their plans. From this point of view, the inclusion of the shift in expectation only in income ex-post is unacceptable. By refining expectations at the end of a particular prospect, a new forecast of the cash flows alters not only the value of the capital at the end of the period, but also the initial volume of the capital. Table 8 shows the calculation of reviewed $K_{0, \text { exp }}$ which respects the new anticipation of the future cash inflows.

Tab. 8: The value of the capital $K_{0, \exp }$ as at the end of Prospect I change in expectations

\begin{tabular}{|c|c|c|c|}
\hline Year & Expected CF & Discount factor & PV of expected CF \\
\hline $\mathbf{2 0 0 0}$ & 10000 & 0.90909 & 9090.9 \\
$\mathbf{2 0 0 1}$ & 9000 & 0.82645 & 7438.0 \\
$\mathbf{2 0 0 2}$ & 9000 & 0.75131 & 6761.8 \\
$\mathbf{2 0 0 3}$ & 9000 & 0.68301 & 6147.1 \\
\hline Prospect I & & & $\mathbf{2 9 4 3 7 . 8}$ \\
\hline
\end{tabular}

After incorporating the change in expectations, the new initial value of capital as at the end of period amounts $29437.8 \mathrm{CU}$. The change projected backwards results in the adjustment of value of the capital $K_{0, \text { exp. }}$. The difference, in comparison with the initial value, is the shrinkage of capitalised value of future incomes. In the illustrative example, money value of the capital at the beginning of the period decreases by $2260.8 \mathrm{CU}$ based on new expectations. This leads to capital loss and the worsening of Mr. Smith's economic well-offness. 
Furthermore, the adjustment of the capital value gives rise to the revision of income ex-ante. Its new volume is $2943.8 \mathrm{CU}$, i.e. the interest from the capital at the $10 \%$ rate. By deducting the $2260.8 \mathrm{CU}$ capital loss we conclude that income ex-post amounts $683 \mathrm{CU}$. Income ex-post is and has to be principally the same as in the previous approach.

\section{The relevancy of the Hicks' income concept for accounting purposes}

Many economists and accounting theoreticians as well refer to the Hicks' concept of income. Because of the restricted scope of this paper, I will concentrate on reformulation of income ex-ante and income ex-post for accounting purposes introduced by E. Edwards and P. Bell in the 60's of the 20 th century. ${ }^{3}$

\section{The subjective value}

Edwards and Bell (1973) start their work with the Hicks' definition of income. They consider the income to be an economic category which operates with the wealth of an individual regardless the source and nature of expected cash inflows. To calculate an income of business entities we have to define first the thinking that determines the well-offness. According to their opinion, the managers are the only bodies that can make a qualified assessment on the wealth of the entity. The wealth of the business entity is the present value of expected future net cash receipts stemming from the net assets of the entity based on the managers' anticipation.

The income (or profit) is one of the tools to measuring the management's ability to choose the right future actions under the presence of uncertainty. Decision-making relates to the future and it is oriented on alternatives bringing the maximum or at least any profit. The profit as a goal of entrepreneurship is prospective and expected; otherwise, it would not be subject of decision-making. When selecting the best course of future actions, the management evaluates the expected results of those actions that will probably affect the position of the entity in the planning horizon. The planned profit for a particular period is the

3 Among other accountants inspired by Hicks I can mention Chambers (1974), Belkaoui (2004) or Seicht (in Janhuba, 2005). 
basic measure of the net effects of planned transactions and events for that period. Therefore, the management prepares the plans in which he specifies the quantity, prices and their changes for manufactured or hold assets, prices and changes in prices for hired production factors, amount of liabilities, etc.

The reality always differs from expectations and the evaluation of expectational errors enables the management to:

- control the real course of business activities and to take measures to correct the unfavourable development, if possible,

- constitute new anticipations, change the plan and to launch new procedures.

Each firm wants to hold such a structure of assets, liabilities and equity, which maximizes the expected profit. The management has to decide on volume, structure and financing of assets. A rationally acting management selects such a structure of assets (under their total market value given) bringing the most expedient cash inflow. The estimation of the amount of this cash inflow is subjective. Cash flows from the selected arrangement of the assets generate value to the firm. The inequality of subjective values of possible alternatives makes the management to prefer the variant with the maximum subjective value and maximum profit as well. The subjective value of the assets has to be higher than their market value; otherwise, it would be better to cease the business. Edwards and Bell call the difference between the subjective value of the assets and their market value by the term subjective goodwill.

\section{The expected subjective profit}

The business plan contains a pattern of expected cash inflows that generates the subjective value of assets. The decision making process does not end when management selects the plan maximizing the subjective goodwill. The maximization is a continual process and managers have to react to the changing market condition. This is the basic function of management under the uncertainty if the entity's goal is to be a going concern. Regular profit estimation and analysis of the actual profit help to explain the deviation of the real course of actions and its results from the expected situation. 
The subjective value is a synonym for entity's well-offness from the management's point of view. It is the starting point for the calculation of expected subjective profit that is defined as "the amount that could be paid out as dividends in any period without impairing subjective value" (Edwards, 1973, p. 38). This profit is of subjective nature because it is derived from the subjective value of the assets, which is estimated by the managers based on their assessment regarding the future development.

\section{An illustrative example}

The company AS has $10000 \mathrm{CU}$ at its disposal. According to the managers' prediction the highest subjective profit will be generated by purchasing the device $A B C$ which costs exactly $10000 \mathrm{CU}$. The management expects that the device will generate net cash inflows amounting $10000 \mathrm{CU}$ in the next four years (let us suppose that cash flows will occur at the end of each period). The estimated market value of the device after four years is zero; the target interest rate is $10 \%$.

The subjective value of the asset (the device) at the beginning of the first period is $31699 \mathrm{CU}$. At the end of the first year the total subjective value of the entity's assets (the value of the device plus the cash inflow) amounts $34869 \mathrm{CU}$. The subjective value rose by $3170 \mathrm{CU}$ during the period. This is the maximum sum that can be paid out as dividends so that the subjective value of assets at the end of period does not drop below the initial subjective value. Edwards and Bell call this dividend the expected subjective profit. Nevertheless, if we contemplate its nature deeper we can conclude that the expected subjective profit is Hicks' income ex-ante conceptually.

If the annual cash inflow (i.e. $10000 \mathrm{CU}$ ) is paid out as dividends at the end of each period, the subjective profits for the next three years will be $2487 \mathrm{CU}, 1736 \mathrm{CU}$ and $909 \mathrm{CU}$. The decreasing amount of subjective profits is the result of decreasing subjective value of the device that will be zero at the end of the fourth year. The subjective value of the entity's total assets diminishes if paid out dividends exceed the amount of subjective profits. The unchanged subjective value of the assets could be assured by paying out dividends equal to the subjective profits. Furthermore, the same situation (the unchanged subjective value of the assets) can be achieved by paying out the subjective profit as a perpetual dividend. This situation happens if the residuum, computed as net cash 
flow for the period less subjective profit, is invested in securities with the rate of return equal to the target interest rate.

We can assert that the subjective profit:

- is subjective in its nature,

- enables to maintain the subjective value of the assets,

- enables to transfer subjective values into market values.

\section{Conclusion}

Edwards and Bell consider three concepts of income, which could be used for accounting purposes. The subjective profit is conceptually coincident with the income ex-ante introduced by J. Hicks. Equation 9 shows the formula for subjective profit. We can make sure that both concepts of income are the same by comparing Equation 9 with Equations $6-8$.

$$
S P^{4}=i \cdot S V_{0}=S V_{1}-S V_{0},
$$

where $S P^{A}=$ the expected subjective profit at the beginning of the period,

$S V_{0}=$ the subjective value at the beginning of the first period,

$S V_{l}=$ the subjective value at the end of the first period,

$i=$ the target interest rate.

$$
S P^{P}=S P^{A}+c=\left(S V_{1}+c\right)-S V_{0},
$$

where $S P^{P}=$ the actual subjective profit for the first period,

$S P^{A}=$ the expected subjective profit at the beginning of the period,

$c=$ the difference between the actual and expected subjective value at the end of the first period,

$S V_{0}=$ the subjective value at the beginning of the first period,

$S V_{l}=$ the subjective value at the end of the first period,

$i=$ the target interest rate.

US GAAP and IFRS require entities to prepare the financial statements free from any subjective judgment as much as possible. Financial statements inform external users about the past events and transactions (despite the sight set forward). Therefore, the traditional accounting conventions refuse the utilization of income ex-ante (or expected 
subjective profit) which is a wholly anticipated category as a measure of the entity's performance for an accounting period. To explore the usefulness and applicability of the Hicks' concept of income, we have to turn our attention to income ex-post (or actual subjective profit). Equation 10 constitutes its alternative definition. Does the note on the subjective nature of the subjective profit hold only for income ex-ante or is it in effect for income ex-post as well?

Considering the variables in Equation 10, we could conclude that not only the expected subjective profit (income ex-ante) but also the actual subjective profit (income ex-post) are subjective in their nature. The subjective value is derived as the present value of expected future cash inflows. It is obvious that both the expected and the actual profit depend on the anticipation of the results of future transactions and events. The subjective expectations of the management are projected into the subjective values at the beginning and at the end of each period. The subjective value of net assets ascertained at the end of period depends on the new expectations regarding the interest rates, prices, costs, etc. At the end of each period the original business plan is revised and the difference between the original and the new subjective value cannot serve as a measure for decision making regarding the allocation of scarce resources by external users.

Income ex-post is not applicable in financial reporting because it cannot be objectively measured. Income ex-post is not utilizable as a tool for the internal management of the entity. One of the main managers' tasks is to evaluate continually the real course of business activities of the entity and to take measure to correct eventually unfavorable results. The evaluation of the fulfillment of the plan requires comparing forecasted and actual profits. The determination of income ex-post for the need of comparison cannot dispense with the revision of all the factors incorporated in the original plan. The revision of the plan always depends on the subjective assessments of the managers. Therefore, the real course of earnings process would not be compared with the original plan but with the revised plan. Of course this problem suspends the possibility of using Hicks' income ex-post in the internal management or (let us say) in the cost accounting.

After summarizing the previous exposition, I can assert that Hicks' concept of income could not be used in financial reporting because: 
- both income ex-ante and income ex-post crucially depend on expectations of the managers who have to estimate the future development and distribution of cash inflows, the level of the interest rate and the length of the time span for which the plan will be compiled,

- the choice of proper interest rate for discounting cash inflows is not unambiguous,

- it is not clear how to tackle with the movements of the discount rate; the importance of this issue is multiplied by the fact that interest rates have the biggest impact in sensitivity analyses,

- a mere change in expectations would affect the amount of both income ex-ante and income ex-post; unfortunately the problem how to cope with these changes is still not resolved - do the changes have an impact on the income ex-post only or do new expectations alter initial value of the capital and income ex-ante, too? (i.e. can we consider the changes in expectations as income or are they capital value changes?),

- the income based on the present value of expected cash inflows is relatively easily applicable for a particular asset or group of similar assets; accuracy and reliability of calculation diminish when taking in account the entity as a whole,

- the application of this income concept on a enterprise level could elicit the illusion that the final result of the calculation indicates the value of the enterprise; a conclusion which is not true,

- even if we succeed to overcome above-mentioned complication, we still have to resolve the problem regarding the interest rate for discounting cash inflows generated by all company's net assets together.

Having summarized the previous exposition, I can assert that Hicks' concept of income could not be used in cost accounting because:

- income ex-post requires revising the original business plan, a fact which precludes the possibility to use this concept of income as a standard tool for the comparison of the actual course of actions with the expected one.

Despite mentioned disadvantages, we cannot a priori deprecate Hicks' concept of income for accounting purposes. There is one important area where his concept finds its usefulness. Income ex-ante (or expected subjective profit) is used in decision-making. Managers usually consider a 
wide range of options for future economic activities. They act according to the economic principles when selecting the best alternative of future action. One of these principles is the effort to maximize the profit. In this context, the management strives to find and to choose the alternative that ensures the highest subjective goodwill.

In my opinion, there are two cases when the Hicks' concept of income is or could be utilized in financial accounting. IAS 36 operates with recoverable amount for testing the impairment of assets. The recoverable amount equals the higher value of the next two:

- the market price of asset (or fair value of asset less estimated selling costs),

- the value in use.

The formula for the calculation of the value in use fully corresponds to income ex-ante for a particular asset. According to IAS 36, the value in use should be computed not only for a single asset but also for a group of assets (the so-called cash generating unit).

The major strength of Hicks' concept of income is not in the area of measuring the effectiveness of the business activity, but in other very similar area. Let us call J. Hicks' assertion that the practical purpose of income calculation is to serve as a guide for prudent behavior again. Being aware, that income is determined as the difference between two volumes of capital I believe that Hicks' main contribution to accounting consists in his emphasis on capital maintenance. The economic concept of income is based on the capital and changes in its value. The users of financial statements should be highly alert as far as possible erosion of capital concerns. This could endanger the future existence of the enterprise and the future source of business income and future stream of dividends distributed to owners as well. Conventional accounting, which prefers measuring the assets at their historical costs, prevents the users from evaluating "real" value of the capital, which is significantly influenced by changing market prices. It should be taken into consideration the introduction of an additional set of financial statements, which should be in line with Hicks' concept of income. This could help users to understand better the entity's well-offness while facing economic uncertainty and continuously changing prices. 


\section{References}

[1] Barlev, B. - Haddad, J. R. (2003): Fair Value Accounting and the Management of the Firm. Critical Perspectives on Accounting, 2003, vol. 14, no. 4, pp. 383-415.

[2] Belkaoui, A. R. (2004): Accounting Theory. London, International Thomson Computer Press, 2004.

[3] Chambers, R. J. (1974): Accounting, Evaluation and Economic Behavior. Houston, Scholars Book, 1974.

[4] Edwards, E. O. - Bell, P. W. (1973): The Theory and Measurement of Business Income. Berkeley, University of California Press, 1973.

[5] FASB (1984): Statement of Financial Accounting Concepts 5. [on-line], Norwalk, Financial Accounting Standards Board, c2009, [cit. 26th March, 2009], <http://www.fasb.org/status/statpg-con5.shtml>.

[6] Fisher, I. (1906): The Nature of Capital and Income. New York, Macmillan, 1906.

[7] Fisher, I. (1930): The Theory of Interest. New York, Macmillan, 1930.

[8] Hicks, J. R. (1946): Value and Capital: An Inquiry into Some Fundamental Principles of Economic Theory. Oxford, Clarendon Press, 1946.

[9] Hitz, J. M. (2007): The Decision Usefulness of Fair Value Accounting - A Theoretical Perspective. European Accounting Review, 2007, vol. 16, no. 2, pp. 323-362.

[10] Janhuba, M. (2005): Základy teorie účetnictví. Praha, Oeconomica, 2005.

[11] Knight, F. H. (1921): Risk, Uncertainty, Profit. Boston, Houghton Mifflin, 1921.

[12] MacNeal, K. (1979): Truth in Accounting. Houston, Scholars Books, 1979.

[13] Mises, L. von (1966): Human Action: A Treatise on Economics. Chicago, Contemporary Books, 1966. 


\title{
The Hicks' Concept of Income and Its Relevancy for Accounting Purposes
}

\author{
David PROCHÁZKA
}

\begin{abstract}
The paper analyses the possibility of using the economic concept of income introduced by J. R. Hicks for accounting purposes. Despite some disadvantages hindering from its broader practical utilization, this concept still finds its place in the area of managerial accounting and capital maintenance. Some aspects of Hicks' income concepts can be even found in International Financial Reporting Standards.
\end{abstract}

Key words: J. R. Hicks; Ex-ante income; Ex-post income; Subjective value; Subjective goodwill; Subjective profit.

JEL classification: M41. 